\title{
Construction of a recombinant avipoxvirus expressing the env gene of Zika virus as a novel putative preventive vaccine
}

\author{
Carlo Zanotto ${ }^{1}$, Francesca Paolini ${ }^{2}$, Antonia Radaelli ${ }^{*+}$ (iD and Carlo De Giuli Morghen ${ }^{3 \dagger}$
}

\begin{abstract}
Background: Zika virus (ZIKV) has been declared a public health emergency that requires development of an effective vaccine, as it might represent an international threat.

Methods: Here, two novel DNA-based (pVAXzenv) and fowlpox-based (FPzenv) recombinant putative vaccine candidates were constructed that contained the cPrME genes of ZIKV. The env gene inserted into the fowlpox vector was verified for correct transgene expression by Western blotting and by immunofluorescence in different cell lines. The production of virus-like particles as a result of env gene expression was also demonstrated by electron microscopy. BALB/c mice were immunosuppressed with dexamethasone and immunized following a prime-boost strategy in a heterologous protocol where pVAXzenv was followed by FPzenv, to evaluate the immunogenicity of the Env protein. The mice underwent a challenge with an epidemic ZIKV after the last boost.

Results: These data show that the ZIKV Env protein was correctly expressed in both normal human lung fibroblasts (MRC-5 cells) and green monkey kidney (Vero) cells infected with FPzenv, and that the transgene expression lasted for more than 2 weeks. After mucosal administration of FPzenv, the immunized mice showed specific and significantly higher humoral responses compared to the control mice. However, virus neutralizing antibodies were not detected using plaque reduction assays.

Conclusions: Although BALB/C mice appear to be an adequate model for ZIKV infection, as it mimics the natural mild infection in human beings, inadequate immune suppression seemed to occur by dexamethasone and different immune suppression strategies should be applied before challenge to reveal any protection of the mice.
\end{abstract}

Keywords: Zika virus, Recombinant vaccines, Fowlpox virus, Prime-boost vaccination, Immune response, Electron microscopy

*Correspondence: antonia.radaelli@unimi.it

${ }^{\dagger}$ Antonia Radaelli and Carlo De Giuli Morghen: Joint last authors ${ }^{1}$ Laboratory of Molecular Virology and Recombinant Vaccine

Development, Department of Medical Biotechnologies and Translational

Medicine, University of Milan, Via Vanvitelli 32, 20129 Milan, Italy

Full list of author information is available at the end of the article

\section{Highlights}

1. A recombinant avipoxvirus was constructed to express the env gene of Zika virus

2. Novel putative recombinant vaccines were used in a prime-boost immunization regimen

3. Mucosal immunization enhances the humoral immune response

(c) The Author(s) 2021. Open Access This article is licensed under a Creative Commons Attribution 4.0 International License, which permits use, sharing, adaptation, distribution and reproduction in any medium or format, as long as you give appropriate credit to the original author(s) and the source, provide a link to the Creative Commons licence, and indicate if changes were made. The images or other third party material in this article are included in the article's Creative Commons licence, unless indicated otherwise in a credit line to the material. If material is not included in the article's Creative Commons licence and your intended use is not permitted by statutory regulation or exceeds the permitted use, you will need to obtain permission directly from the copyright holder. To view a copy of this licence, visit http://creativecommons.org/licenses/by/4.0/. The Creative Commons Public Domain Dedication waiver (http://creativeco mmons.org/publicdomain/zero/1.0/) applies to the data made available in this article, unless otherwise stated in a credit line to the data. 


\section{Background}

Zika virus (ZIKV) was first isolated in 1947 from rhesus macaques in the Zika Forest Research Station of Uganda, and was then identified in Aedes africanus mosquitoes from the same forest [1]. ZIKV belongs to the Flavivirus genus of the Flaviviridae family, which includes the Dengue, Yellow fever, West Nile, Japanese encephalitis, and Tick-borne encephalitis viruses, which have singlestranded, positive-sense RNA genomes of around $11 \mathrm{~kb}$ [2]. In particular, ZIKV shows antibody cross-reactivity to the four serotypes of Dengue virus [3]. Although ZIKV might also be sexually and vertically transmitted [4, 5], bites by Aedes aegypti and Aedes albopictus mosquitos represent the main route of ZIKV infection in humans [6].

Human infections were initially reported in Nigeria in 1954 [7], but the first major outbreak occurred in 2007 on Yap Island, in the Federated States of Micronesia, where almost $75 \%$ of the population was shown to be infected, and almost $20 \%$ developed symptomatic disease [8]. Large outbreaks also occurred in French Polynesia in 2013 [9], and in South America [10]. ZIKV infections are mainly asymptomatic, but in spite of the generally mild self-limiting symptoms associated with maculopapular rash, headache, conjunctivitis, and musculoskeletal pain, neurological complications can occur, such as microcephaly in the developing fetus [4]. ZIKV has also been associated with Guillain-Barré syndrome in adults, an autoimmune neurological disease that is characterized by muscle weakness, motor dysfunction, and in some cases, paralysis $[10,11]$, as the virus can infect human neural progenitor cells [12].

Thus, since its introduction into Brazil in 2015, ZIKV has been declared a public health emergency of international concern by the World Health Organization [13], as it might represent an international threat [14]. Considering also its easy transmission from asymptomatic patients, rapid development of a safe and effective vaccine is required to prevent further outbreaks.

Currently, there have been many attempts to develop candidate vaccines against ZIKV [15-17] that have included subunit and recombinant plasmid-based vaccines, inactivated or live-attenuated viral vaccines, recombinant vaccines $[18,19]$, and virus like particles (VLPs) [20, 21]. All these have shown different efficacies in mice and nonhuman primate models [20, 22-27]. Some of them have also been advanced to clinical evaluation, and are undergoing phase I and II clinical trials [12, 13, 28, 29].

Attenuated viral-vectored vaccines are among the most effective immunogens against infectious diseases [30, 31], as they are potent stimulators of antibodies and cell-mediated immunity, and they can protect against both homologous and heterologous virus strains [32]. In particular, avipox viruses have taken on an important role in the development of novel recombinant immunogens, as they do not replicate in most mammalian cells, although permissive for entry and transgene expression [33, 34]. Moreover, avipoxvirus vectors do not cause the undesired side effects induced by vaccinia-based recombinants, and they are not neutralized in individuals who have already been immunized against smallpox [35]. In particular, Fowlpox (FP)-based recombinants can express foreign antigens for long periods and induce protective immunity in mammals [36-38].

The structural proteins encoded by ZIKV after posttranslational processing of the RNA genome include the capsid (c), the membrane precursor or pre-membrane $(\mathrm{Pr})$, the membrane $(\mathrm{M})$, and the envelope (E) proteins. In particular, the envelope proteins of flaviviruses show very similar structures and functions, as they can mediate virus cell fusion [39] and elicit a cell-mediated response [40]. They are therefore the main targets of neutralizing antibodies, and can be related to ZIKV neurotropism [39].

Here, we report on the construction of a novel DNA recombinant (pVAXzenv) and a novel FP recombinant (FPzenv) putative vaccines that contain the $c \operatorname{PrME}$ genes of ZIKV (Fig. 1). This sequence is related to cellular entry, and we evaluate the immunogenicity of the Env protein in a mouse model after challenge with an epidemic ZIKV strain. The final aim was to use the pVAXzenv recombinant as a prime and the FPzenv recombinant as a boost, administered also by the mucosal route. This novel FP construct was used to infect chick embryo fibroblasts (CEFs), normal human lung fibroblasts (MRC-5 cells), and green monkey kidney (Vero) cells to assess transgene expression in vitro. Transcript expression in Vero cells was tested to determine whether FPzenv induces longlasting responses. The production of VLPs, as a result of env gene expression, was also verified by electron microscopy. Mice immunization was performed by priming the animals with pVAXzenv by in-vivo electroporation (e.p.) and boosting them by subcutaneous (s.c.) and intranasal (i.n.) administration of the FPzenv. Humoral responses were verified before all bleeding times, and the virus neutralizing activity was tested before the challenge. The challenge with ZIKV was performed, after the last boost, on mice immunosuppressed with dexamethasone. The experimentally immunized mice showed significantly higher antibody responses compared to the controls, especially after FPzenv administration by the mucosal route. Viral neutralizing activity could not be demonstrated, as well as protection after the challenge with ZIKV, as all of the mice survived. 


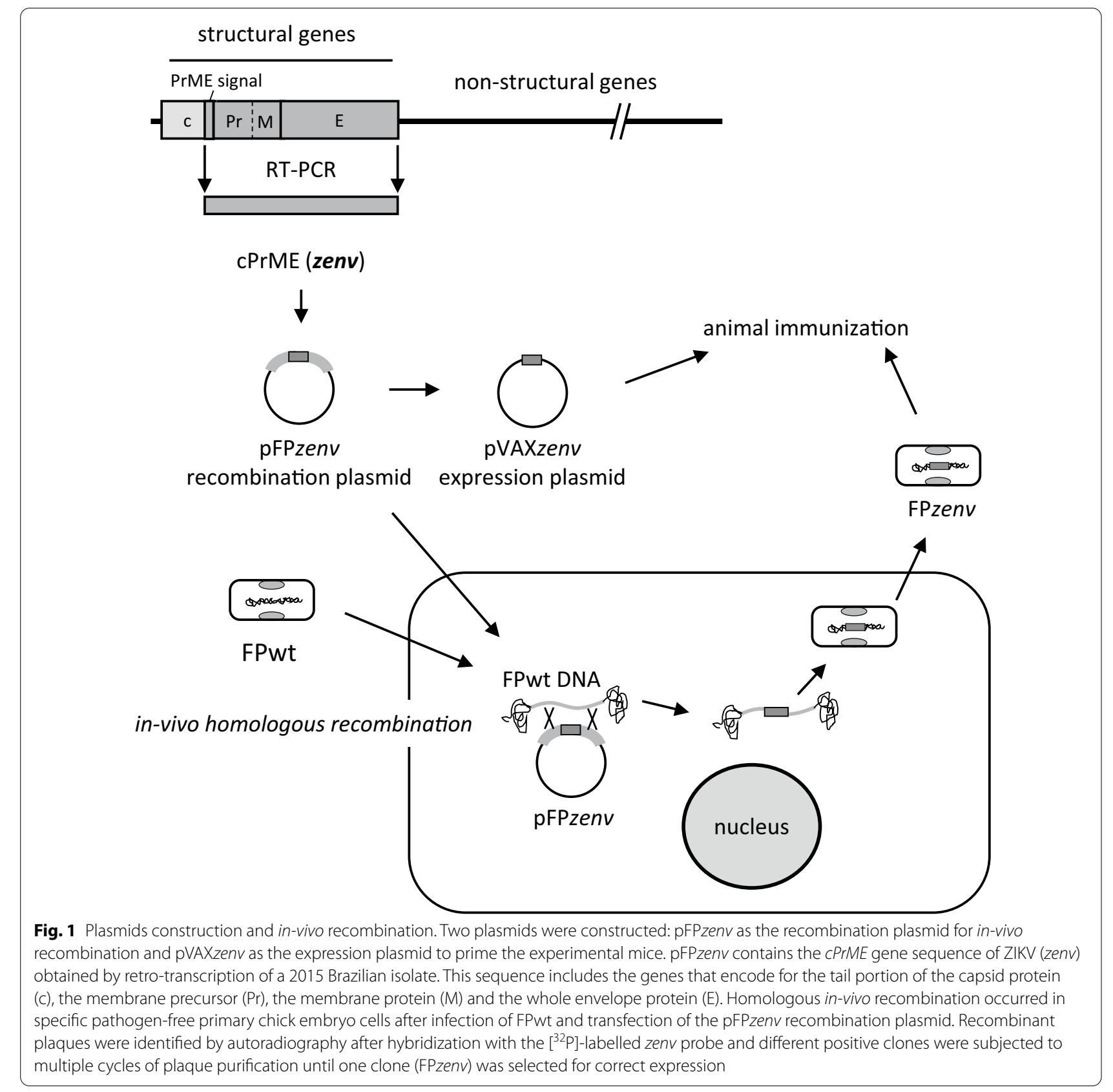

\section{Material and methods}

\section{Cells}

Specific-pathogen-free primary CEFs were grown in Dulbecco's Modified Eagle's Medium (DMEM) supplemented with $5 \%$ heat-inactivated calf serum (Gibco Life Technologies, Grand Island, NY, USA), 5\% Tryptose Phosphate Broth (Difco Laboratories, Detroit, MI, USA), $100 \mathrm{U} / \mathrm{mL}$ penicillin, and $100 \mu \mathrm{g} / \mathrm{mL}$ streptomycin. MRC-5 and Vero cells were grown in DMEM supplemented with $10 \%$ heat-inactivated calf serum, with $100 \mathrm{U} / \mathrm{mL}$ penicillin and $100 \mu \mathrm{g} / \mathrm{mL}$ streptomycin.

\section{Recombination plasmid}

The plasmid prepared for in-vivo recombination contained the $c \operatorname{PrME}$ gene sequence of ZIKV (Fig. 1). This fragment included the whole envelope gene sequence (54.38 $\mathrm{kDa} ; 504$ amino acids), as well as the genes that encode for part of the capsid protein $(\sim 2 \mathrm{kDa} ; 18$ amino 
acids), the membrane precursor $(10.12 \mathrm{kDa} ; 92$ amino acids), and the membrane protein $(8.4 \mathrm{kDa} ; 76$ amino acids) [41]. In particular, the capsid hydrophobic tail is a signal peptide for the translocation of PrM to the endoplasmic reticulum [42], whereas PrM prevents the rearrangements of the envelope proteins in an acidic milieu, and their fusion with cell membranes during translocation through the secretory pathway.

The ZIKV RNA genome was obtained from the serum of a 2015 Brazilian patient (ZikaSPH2015 strain) and was supplied by the EVAg project through the courtesy of M.R. Capobianchi (National Institute for Infectious Diseases L. Spallanzani, I.N.M.I., Rome, Italy). It was retrotranscribed and amplified using the forward V436 $\left(5^{\prime}\right.$ CCG CGC CCG GGA AGC TTA TGG GCG CAG ATA CTA GTG TC $3^{\prime}$ ) primer and reverse V437 (5' GGG GTA CCG CGG CCG CAT AAA AAT TAA GCA GAG ACG GCT GTG GA $3^{\prime}$ ) primer, to get the $c \operatorname{PrME}$ fragment. The primers were designed to include the SmaI/HindIII sites at the $5^{\prime}$ end, followed by the ATG sequence, and the NotI/KpnI sites at the $3^{\prime}$ end. These sites were needed to clone the ZIKV cPrME gene fragment into the pFP recombination plasmid. At the $3^{\prime}$ end, a T5NT sequence was also added, as an additional poxviral transcription termination signal.

RNA (10 ng) was retro-transcribed using Transcriptor One-Step RT-PCR kit (Roche Molecular Systems, Indianapolis, IN, USA) in $50 \mu \mathrm{L}$ following the manufacturer instructions.

After deletion of the $A 27 \mathrm{~L}$ gene from $\mathrm{pFP}_{\mathrm{A} 27 \mathrm{~L}}$ recombination plasmid $[43,44]$ and subcloning of the $c \operatorname{Pr} M E$ fragment, the resulting pFP $C P r M E 18$ clone was sequenced to exclude any possible mistakes due to the PCR amplification. A non-synonymous mutation at nucleotide 759, where the cytosine nucleotide had replaced the thymine giving origin to an alanine instead of a valine, was corrected by site-specific mutagenesis $[45,46]$.

The $c \operatorname{PrME}$ mutagenized fragment was thus inserted inside the 3 - $\beta$-hydroxysteroid dehydrogenase 5 -delta 4 isomerase gene, downstream of the Vaccinia virus $\mathrm{H} 6$ (H6) early/ late promoter [47]. The sequence was aligned with the env gene of ZIKV (GenBank accession number KU991811) using Align Plus 2.0. This pFPcPrME recombination plasmid $(10,274 \mathrm{bp})$ was finally designated as pFPzenv.

\section{Recombinant fowlpox virus}

The FPzenv viral recombinant putative vaccine was generated by in-vivo homologous recombination [48]. Briefly, FPzenv was obtained on specific pathogenfree primary CEFs, using the recombination plasmid pFPzenv described above $(62.5 \mu \mathrm{g})$ and the wild-type FP virus (5 PFU/cell). Recombinant plaques were identified by autoradiography after hybridization with the $\left[{ }^{32} \mathrm{P}\right]$-labelled zenv probe. Recombinants were subjected to multiple cycles of plaque purification until one clone was selected for correct expression. The recombinant was amplified in CEFs, purified on discontinuous sucrose density gradients, and titrated essentially as described previously [49]. Briefly, the cells were harvested, ultracentrifuged at $30,000 \times g$ for $2 \mathrm{~h}$ at $4{ }^{\circ} \mathrm{C}$, and the pellets were resuspended in $1 \mathrm{mM}$ Tris, $150 \mathrm{mM} \mathrm{NaCl}, 1 \mathrm{mM}$ EDTA, pH 7.4. After addition of trypsin $(0.06 \%$ final concentration), the pellet was incubated for $5 \mathrm{~min}$ at $37^{\circ} \mathrm{C}$, and the virus was released from the cells by sonication. The supernatant was overlaid onto a discontinuous $30 \%$ to $45 \%(\mathrm{w} / \mathrm{w})$ sucrose gradient, in the same buffer. After ultracentrifugation at $38,000 \times g$ for $1 \mathrm{~h}$, the viral band at the interface was recovered, diluted with $1 \mathrm{mM}$ Tris$\mathrm{HCl}, \mathrm{pH} 9$, and pelleted at $67,000 \times g$ for $1 \mathrm{~h}$. The purified virus was resuspended in $\mathrm{Ca}^{2+}$-free and $\mathrm{Mg}^{2+}$-free phosphate-buffered saline $\left(\mathrm{PBS}^{-}\right)$, briefly sonicated, and then aliquoted and frozen at $-80{ }^{\circ} \mathrm{C}$ until use.

\section{Expression plasmids}

Two expression plasmids, pVAXgag/proM766 (here referred to as pVAXgp) and pVAXzenv, were used to prime the mice. pVAXgp contains the SIVmacM766 gag/ pro gene [50], which was a kind gift from G. Franchini (National Cancer Institute, NIH, Bethesda, MD, USA), and was used as an irrelevant negative control. The zenv gene was excised from pFPzenv and inserted into the pVAX expression plasmid (Invitrogen Corp., San Diego, CA, USA), which contained the human CMV promoter and is approved for use in humans. Transformation was performed using JM109 competent bacteria, in the presence of $50 \mu \mathrm{g} / \mathrm{mL}$ kanamicin, as pVAX contains the kanamicin resistance gene. Briefly, the zenv gene was cut from pFPzenv with HindIII/NotI and inserted into the pVAXenvM766 plasmid, from where the envM766 gene had been previously removed using the HindIII/NotI/SalI restriction enzymes. Bacterial selection was performed by PCR amplification using the V438/V441 primers, and $2.5 \mathrm{mM} \mathrm{MgCl} 2$. Amplification was carried out starting from $1 \mu \mathrm{L}$ of each bacterial colony in a final volume of 20 $\mu \mathrm{L}$ in a mixture containing $1 \mu \mathrm{M}$ of each primer, $200 \mu \mathrm{M}$ of each dNTP, $2.5 \mathrm{mM} \mathrm{MgCl}_{2}$, and $0.025 \mathrm{U} / \mu \mathrm{L}$ Taq DNA polymerase (Fermentas). The PCR conditions were: $94{ }^{\circ} \mathrm{C}$ for $2 \mathrm{~min}$, followed by 30 cycles at $94{ }^{\circ} \mathrm{C}$ for $30 \mathrm{~s}, 51{ }^{\circ} \mathrm{C}$ for $30 \mathrm{~s}, 72{ }^{\circ} \mathrm{C}$ for $45 \mathrm{~s}$, and extension at $72{ }^{\circ} \mathrm{C}$ for $7 \mathrm{~min}$ (PTC-200 thermocycler; MJ Research, Waltham, MA, USA).

\section{ZIKV amplification}

Vero cells were infected for $1 \mathrm{~h}$ at $37{ }^{\circ} \mathrm{C}$ with $0.4 \mathrm{PFU}$ ZIKV (MR766 strain), a kind gift from M.R. Capobianchi 
(I.N.M.I.), and maintained in DMEM with 5\% heatinactivated calf serum. After 5 days, the cells were harvested, disrupted, and centrifuged at $400 \times g$ for $5 \mathrm{~min}$. The supernatant was then aliquoted and titered according to the Vero cells.

\section{Western blotting}

To determine whether the Env protein was expressed, replication nonpermissive Vero cells were infected for $1 \mathrm{~h}$ at $37^{\circ} \mathrm{C}$ using FPzenv (10 PFU/cell). After overnight incubations, the samples were collected, run on $12.5 \%$ polyacrilamide gels, and examined by Western blotting, as described previously $[51,52]$. The blotted nitrocellulose membranes were incubated overnight at $4{ }^{\circ} \mathrm{C}$ using the human polyclonal anti-ZIKV-specific serum (dilution, 1:200), and rabbit polyclonal antibodies or mouse monoclonal antibodies (always at dilution 1:500). The primary antibodies were followed by horseradish-peroxidase-conjugated secondary antibodies, as goat anti-human serum (dilution, 1:1,000; DakoCytomation, Carpinteria, CA, USA) or goat anti-rabbit (dilution, 1:2,000) or goat antimouse (dilution, 1:1,000). After a 1-h incubation and 2-h washes, the proteins were revealed using the ECL system (Western Lightning Plus-ECL; PerkinElmer, Waltham, MA, USA) followed by exposure of the nitrocellulose membranes to a hyperfilm for different times (Amersham Hyperfilm ECL; GE Healthcare, Buckinghamshire, UK). Cells infected with FP wild-type and with ZIKV were used as negative and positive controls, respectively.

\section{Immunofluorescence}

Immunofluorescence was carried out as already described [53], using CEFs and Vero and MRC-5 cells, to examine the expression and subcellular localization of the ZIKV Env protein. Briefly, the cells were seeded at a density of $5 \times 10^{5} / 35$-mm-diameter dish on sterile glass coverslips. After infection with FPzenv (5 PFU/cell; except for CEFs, which were infected with $0.5 \mathrm{PFU}$ ) at $37^{\circ} \mathrm{C}$ for $1 \mathrm{~h}$, the cells were incubated overnight at $37^{\circ} \mathrm{C}$ in DMEM supplemented with $2 \%$ fetal calf serum. The cells were then washed twice with $\mathrm{PBS}^{-}$, and fixed with $2 \%$ paraformaldehyde (Polysciences) in $\mathrm{PBS}^{-}$for $10 \mathrm{~min}$ at room temperature, followed by $100 \%$ cold acetone for $5 \mathrm{~min}$ at $4{ }^{\circ} \mathrm{C}$. The samples were incubated with the 1:100-diluted human polyclonal anti-ZIKV serum, which was a kind gift from M.R. Capobianchi, or with the 1:50-diluted rabbit polyclonal anti-Env serum (GeneTex Int. Corp., Inc., Irvine, CA, USA), or with the 1:50-diluted mouse monoclonal anti-Env antibody (GeneTex). The primary antibody was followed by the 1:50-diluted FITC goat anti-human or sheep anti-rabbit or goat anti-mouse antiserum (Cappel, MP Biomedicals, Inc., Aurora, OH, USA). FPwt and ZIKV that were previously produced in our laboratory were used to infect the cells, as negative and positive controls, respectively. The samples were viewed under a fluorescence microscope (Axioskop; Zeiss).

\section{Ultrastructural analysis by transmission electron microscopy}

Confluent MRC-5 and Vero cells were infected with 6 or 4 or 2 or $1 \mathrm{PFU} /$ cell FPzenv, and CEFs with 0.05 or 0.1 or $0.5 \mathrm{PFU} /$ cell, for $1 \mathrm{~h}$ at $37^{\circ} \mathrm{C}$, and were collected 3 days post infection (p.i.). ZIKV was used at $1 \mathrm{PFU} /$ cell as the positive control. Inclusion was performed as already described [38]. Briefly, after centrifugation at $1,000 \times \mathrm{g}$ for $10 \mathrm{~min}$, the cells were all fixed in $2.5 \%$ glutaraldehyde (Polysciences, Warrington, PA, USA) in $0.1 \mathrm{M} \mathrm{Na}$ cacodylate buffer, $\mathrm{pH} 7.4$, for $1 \mathrm{~h}$ at $4{ }^{\circ} \mathrm{C}$, and then rinsed twice and post-fixed in cacodylate-buffered $1 \% \mathrm{OsO}_{4}$ at $4{ }^{\circ} \mathrm{C}$ for $1 \mathrm{~h}$. The specimens were dehydrated through a series of graded ethanol solutions and propylene oxide, and embedded in Poly/Bed 812 epoxy resin mixture. Sectioning was performed with an ultramicrotome (MT2B; Sorvall, New York, NY, USA) equipped with a diamond knife. After staining with water-saturated uranyl acetate and $0.4 \%$ lead citrate in $0.1 \mathrm{M} \mathrm{NaOH}$, ultra-thin sections were examined using an electron microscope (CM10; Philips, Eindhoven, The Netherlands).

\section{Expression over time of viral RNA transcripts in Vero cells}

Confluent replication-restrictive Vero cells $\left(1.5 \times 10^{6}\right.$ cells/Petri dish; diameter, $5 \mathrm{~cm}$ ) were infected with FPzenv at $5 \mathrm{PFU} /$ cell for $1 \mathrm{~h}$ at $37{ }^{\circ} \mathrm{C}$. The cells were rinsed twice with $\mathrm{PBS}^{-}$, scraped from the Petri dishes with a rubber policeman every 3 days for 4 weeks, and centrifuged at $1500 \times g$ for $5 \mathrm{~min}$ at room temperature. Cell lysis and RNA extraction were performed according to the QIagen RNeasy mini kit protocol, following the manufacturer instructions, with minor modifications. Briefly, $350 \mu \mathrm{L}$ RLT lysis buffer was added to the cell pellets, which were resuspended before freezing at $-80{ }^{\circ} \mathrm{C}$. When all of the samples were ready, RNA extractions started by adding to each sample one volume $75 \%$ ethanol. The RNA was transferred to the kit columns, which were then centrifuged for $15 \mathrm{~s}$ at $8000 \times g$ at room temperature. The columns were washed four times with wash buffer, as indicated by the manufacturer. The DNase treatment, after the first wash/ centrifugation cycle with $500 \mu \mathrm{L}$ RPE, was also performed using the DNaseI incubation mix (QIagen, RNase-free DNase sets; $10 \mu \mathrm{L}$ DNaseI in $70 \mu \mathrm{L}$ RDD buffer). After the last wash with $500 \mu \mathrm{L}$ $\mathrm{RPE}$, elution was performed with $60 \mu \mathrm{L}$ RNase/DNasefree water, and the RNA concentrations were determined using a spectrophotometer (SmartSpec 3000; BioRad, Hercules, CA, USA). RT-PCR was performed using RTPCR system kit (Access; Promega, Madison, WI, USA). 
Briefly, 50 ng RNA was used in a final volume of $20 \mu \mathrm{L}$ in the presence of $1 \mu \mathrm{M}$ of each primer, $250 \mu \mathrm{M}$ of each $\mathrm{dNTP}, 1 \mathrm{U}$ Thermus filiformis DNA polymerase, $1 \mathrm{U}$ Avian Myeloblastosis Virus reverse transcriptase, and $3 \mathrm{mM} \mathrm{MgSO}_{4}$. The ZIKV env-specific primers V438 and V441 were used to obtain a 661-bp fragment. RNAs from ZIKV-infected and noninfected Vero cells were used as positive and negative controls, respectively. The reverse transcriptase reaction was performed at $45^{\circ} \mathrm{C}$ for $45 \mathrm{~min}$, followed by $2 \mathrm{~min}$ at $94^{\circ} \mathrm{C}$. PCR amplification was carried out for 40 cycles at $94{ }^{\circ} \mathrm{C}$ for $30 \mathrm{~s}, 58^{\circ} \mathrm{C}$ for $30 \mathrm{~s}$, and $68{ }^{\circ} \mathrm{C}$ for $45 \mathrm{~s}$, followed by a final incubation at $68{ }^{\circ} \mathrm{C}$ for 7 min. $\beta$-actin was amplified, which gave a band of $518 \mathrm{bp}$ using $5 \mathrm{ng}$ RNA in a final volume of $20 \mu \mathrm{L}$, under the conditions described above, except that $1 \mathrm{mM} \mathrm{MgSO}_{4}$ was used. Primers V84 (5' CTG ACT ACC TCA TGA AGA TCC T $3^{\prime}$ nt 630-651) and V85 (5' GCT GAT CCA CAT CTG CTG GAA $3^{\prime}$ nt 1147-1127) were used. The PCR products were run on $1 \%$ agarose gels, and gel images were acquired by Speedlight Platinum apparatus (Lightools Research, Encinitas, CA, USA).

\section{Immunization protocols}

Two groups of 7-week-old female BALB/c mice were used (Charles River Laboratories, Wilmington, MA, USA), as seven mice/group (Fig. 3a). For the control Group 1 (G1), we used the pVAXgp plasmid $(10+50 \mu \mathrm{g} /$ mouse), followed by FPgp $\left(1 \times 10^{6} \mathrm{PFU} /\right.$ mouse $)$, where both the plasmid and the viral recombinants contain the same irrelevant SIVmacM766 gag/pro gene, previously described. For the experimental Group 2 (G2), we used the pVAXzenv plasmid $(10+50 \mu \mathrm{g} /$ mouse), followed by FPzenv $\left(1 \times 10^{6} \mathrm{PFU} /\right.$ mouse $)$ where both the plasmid and the viral recombinants contain the same ZIKV zenv gene, previously described. Before each immunization, the mice were anesthetized by intramuscular (i.m.) injection of $30 \mu \mathrm{L}$ of a mixture of $3.5 \mu \mathrm{L}$ Rompun (stock, $20 \mathrm{mg}$ / $\mathrm{mL}$; Bayer SpA, Milan, Italy) plus $5.7 \mu \mathrm{L}$ Zoletil 100 (Virbac Srl, Milan, Italy) and $35.7 \mu \mathrm{L} \mathrm{PBS}^{-}$. The vaccination course with pVAXgp or pVAXzenv consisted of $50 \mu \mathrm{g}$ i.m. injection and $10 \mu \mathrm{g}$ s.c. injection, followed by electroporation. For the electroporation, one 50-ms transcutaneous low-voltage electric pulse (amplitude, $100 \mathrm{~V}$ ) was administered at the i.m. injection site via a multiple-needle electrode connected to the electroporation apparatus (ECM830, BTX i45-168, Holliston, MA, USA). Priming was followed by four boost administrations of FPzenv: two s.c., one i.n., and one both i.n. and s.c.. Challenge with ZIKV $\left(1 \times 10^{5} \mathrm{PFU} /\right.$ mouse $)$ was performed s.c. at 10 days after the last immunization. For 6 days before the ZIKV challenge and for 4 days after the ZIKV challenge, the mice were immune suppressed with dexamethasone (Soldesam, $4 \mathrm{mg} / \mathrm{mL}$; LFM, Milan, Italy) intraperitoneally
[54]: $50 \mathrm{mg} / \mathrm{kg}$ on the first 2 days, and $25 \mathrm{mg} / \mathrm{kg}$ for the following days. Bleedings were performed from the retroorbital eye plexus before the first immunization (Fig. 3a, T0), before each subsequent immunization (Fig. 3a, T1$\mathrm{T} 5$ ), and at different intervals thereafter, as indicated. The plasma fractions were aliquoted and frozen at $-80{ }^{\circ} \mathrm{C}$. Dexamethasone was withdrawn 4 days after the challenge (T9) and 4 days before the sacrifice (T10, T11).

The mice were also monitored during the whole treatment period for weight loss until euthanasia. The experimental group did not show any significantly differences in weight compared to the control mice, with the weight variations seen as $<15 \%$, compared to the starting period. All of the mice were maintained according to the Italian National Guidelines and the EU Directive 2010/63/EU for animal experiments. They were observed for signs of disease, and provided with food and water ad libitum. Every effort was made to minimize their suffering. Approval for this study was granted by the Ethical Committee of the University of Milan.

\section{Enzyme-linked immunosorbent assay}

The mouse plasma samples from $\mathrm{T} 0$ to $\mathrm{T} 11$ were assayed for antibodies against ZIKV Env-specific proteins using enzyme-linked immunosorbent assays (ELISAs). Vero cells $\left(1.5 \times 10^{6}\right)$ previously infected for 2 days with FPzenv (2 PFU/cell) were used as the antigen, after plating in 96-well microtiter plates (MaxiSorp; Nunc, Thermoscientific, Roskilde, Denmark). Briefly, after infection and washing with $\mathrm{PBS}^{-}$, the cells were freeze-thawed three times, harvested with a rubber policeman, passed through the needle of an insulin syringe $(30 \mathrm{G} \times 8 \mathrm{~mm})$, and centrifuged for $5 \mathrm{~min}$ at $800 \times g$. Following resuspension in $0.05 \mathrm{M}$ carbonate-bicarbonate buffer, $\mathrm{pH} 9.6$ (15 mM Na $2 \mathrm{CO}_{3}, 35 \mathrm{mM} \mathrm{NaHCO}, 0.2 \% \mathrm{NaN}_{3}$ ), $1 \times 10^{5}$ cells in $50 \mu \mathrm{L}$ were added to the wells of 96 -well plates. The antigen was incubated overnight at $4{ }^{\circ} \mathrm{C}$. ELISAs were performed in duplicate, essentially as described previously [55], using serum from each animal of both groups of mice (G1, control group; G2, experimental group) from T0 to T11. The sera dilutions were 1:1,000. The reactions were revealed using goat anti-mouse horseradish-peroxidase-conjugated serum (dilution, 1:1,000; DakoCytomation, Glostrup, Denmark) and tetramethylbenzidine substrate (Sigma-Aldrich). The pre-immune mouse sera (T0) were used as the negative controls. The absorbance of each well was read at $450 \mathrm{~nm}$ using a microplate reader (550; Bio-Rad, Hercules, CA, USA). Inactivated ZIKV $\left(4 \times 10^{5} \mathrm{PFU} /\right.$ well $)$ and the recombinant ZIKV Env-specific protein (10-300 ng, ZIKV envelope domain III, European Virus Archive goes Global, EVAg, Marseille, France) were also used as antigens (serum dilution, 1:100). 


\section{Virus neutralization assays}

The neutralizing activities of the mice sera were determined by measuring the extent of in-vitro inhibition of virus infectivity at T0 (pre-immune serum) and T6 (pre-challenge serum). The assays were performed as previously described [44], by pre-incubation of an equal volume of ZIKV with heat-inactivated mouse serum, used at different dilutions (1:50 to 1:1600, in DMEM without serum) in 48 -well plates, for $1 \mathrm{~h}$ at $37^{\circ} \mathrm{C}$. Briefly, the viral titer was adjusted to provide approximately 80 PFU ZIKV in the assays. The infections were performed in duplicate on confluent Vero cells, and were allowed to proceed for $1 \mathrm{~h}$ at $37^{\circ} \mathrm{C}$. The same amount of virus incubated with DMEM was used as the control. Two days later, $5 \mathrm{~mL}$ medium was added to maintain the correct $\mathrm{pH}$, and 5 days p.i. the cells were fixed in $3 \mathrm{~mL}$ methanol:acetic acid $(3: 1 ; \mathrm{v} / \mathrm{v})$ for $1-3 \mathrm{~h}$ at room temperature. After removing the fixing solution and the agarose overlay, staining was performed using $1 \mathrm{~mL} 2 \%$ crystal violet dye in methanol. The neutralizing activity is expressed as the plaque reduction numbers and calculated by comparing the plaque numbers after incubating the virus with immune sera to the plaque numbers found after incubating the virus with no serum or with preimmune sera.

\section{Viral RNA amplification to determine ZIKV after the challenge}

To determine whether ZIKV was present after the challenge in the vaccinated mice, the viral RNA was extracted from the sera obtained at T7-T11 from the control and experimental mice, using QIAamp viral RNA mini kit (QIagen), according to the manufacturer instructions. Amplifications were performed using 50, 70, 250, 280, $400 \mathrm{ng}$ of each RNA. Sera of some individual mice were also tested using 800 ng RNA. RT-PCR was performed using RT-PCR system kit (Access; Promega), as described above, using primers V438/V441 and under essentially the same conditions, with $3 \mathrm{mM} \mathrm{MgSO}_{4}$ and $58{ }^{\circ} \mathrm{C}$ annealing temperature, which was the most suitable for ZIKV detection.

\section{Statistical analyses}

Statistical analyses were performed using parametric $\mathrm{t}$-tests and areas under the curves (AUCs), using the GraphPad Prism version 2.0 software. Statistical significance was set as $\mathrm{p}<0.05\left(^{(*)}, \mathrm{p}<0.01\left(^{(* *)}\right.\right.$ and $\mathrm{p}<0.001$ $(* * *)$.

\section{Results}

Env is expressed by FPzenv in Vero cells

Protein expression was investigated after infection of nonpermissive simian Vero cells with FPzenv, using
Western blotting (Fig. 2a). A band of $54 \mathrm{kDa}$ was always seen (Fig. 2a, lanes 4), which was also present when the Vero cells were infected with ZIKV (Fig. 2a, lanes 2) as the positive control, both when recognized by the mouse monoclonal antibody and the rabbit polyclonal antibodies. As expected, no specific band was present in the mock-infected cells ( $\mathrm{m}$, lanes 1$)$ or in the cells infected with FP wild-type (wt, lanes 3).

\section{Env is expressed in the cytoplasm by FPzenv}

To determine the subcellular localization of the Env protein expressed by FPzenv, the CEFs and Vero and MRC-5 cells were infected with FPzenv and analyzed by immunofluorescence (Fig. 2b). These data show that the Env protein was expressed mainly in the cytoplasm (Fig. 2b; 2a-c). The intensity of the fluorescence was similar to that observed in the same cells infected with ZIKV (Fig. 2b; 3b-c), except in the CEFs, which were not infected by ZIKV (Fig. 2b; 3a). The FPwt-infected cells were always negative, as expected (Fig. $2 \mathbf{b} ; 1 \mathbf{a}-\mathrm{c}$ ).

\section{FPzenv expresses the transgene in Vero cells for more than 2 weeks}

The expression of the env transgene after infection by FPzenv was also tested over time. The mRNA isolated from the infected Vero cells showed that the gene carried by FPzenv was amplified as a band of $661 \mathrm{bp}$, which was expressed for up to 18 days p.i. (Fig. 2c, lanes 2-7). The expression was similar up to 9 days p.i., and then gradually diminished from 12 to 18 days, and disappeared by 21 days p.i.. The negative control is represented by the mock-infected cells (Fig. 2c, T0, lane 1). $\beta$-actin RNA (518 bp) was similarly amplified in all of the samples, thus confirming the equal levels of total RNA across these different samples.

\section{Virus-like particles were found in Vero cells by electron microscopy}

FPzenv was also used to infect the CEFs and MRC-5 and Vero cells for verification by electron microscopy of the formation of VLPs. Clusters of FPzenv recombinants were seen in the Vero cells corresponding to the viral inoculum (Fig. 2d, left, black arrows), as well as viroplasm (Fig. 2d, left, V) and a few empty VLPs (Fig. 2d, left, white arrows). The ZIKV-infected cells used as the positive control showed large viral progeny in the cytoplasm (Fig. 2d, right, black arrows). No VLPs were seen in the CEFs and MRC-5 cells infected with FPzenv (data not shown). 
Fig. 2 In vitro characterization of FPzenv-mediated transgene expression and VLP formation. a Expression of the Env protein of ZIKV by the FP recombinants in Vero cells. Vero cells were infected by the FP recombinants and examined using Western blotting, to determine the Env protein expression. The Env protein was always detected both when using the monoclonal or the polyclonal antibodies after infection with either ZIKV (Z, lanes 2) or FPzenv (zenv, lanes 4). Mock infected cells ( $m$, lanes 1$)$ and cells infected with FP wild-type (wt, lanes 3) were used as negative controls. b Heterologous protein expression by immunofluorescence in the CEFs and the Vero and MRC-5 cells. Immunofluorescence of the infected cells was performed to determine the subcellular localization of the Env protein expressed by FPzenv. The Env protein was expressed mainly in the cytoplasm $(2 a-2 b-2 c)$, and the intensity of the fluorescence signals was generally lower in cells infected with the recombinant than in the same cells infected with ZIKV (3b-3c). ZIKV did not infect the CEFs (3a). No immunofluorescence was detected in the FP-wild-type-infected cells used as negative controls (1a-1b-1c). c Expression of the env transcripts over time by FPzenv in replication-restrictive Vero cells. After infection of the Vero cells with FPzenv, the expression of the transgene was evaluated by RT-PCR every 3 days, over 27 days. The expression levels for FPzenv transcripts (661 bp) remained up to day 18 p.i.. Amplification of $\beta$-actin mRNA (518 bp) is shown. $\mathbf{d}$ Electron microscopy. Vero cells were infected with FPzenv to verify production of virus-like particles (VLPS). Left. Some empty VLPs were seen (white arrows), as well as clusters of FPzenv recombinants corresponding to the viral inoculum (black arrows) and DNA viral factories (V); bar, $0.2 \mu \mathrm{m}$. Inset, VLPs enlargement; bar, $50 \mathrm{~nm}$. Right. ZIKV-infected cells (black arrows) were used as the positive control, and clusters of virus particles (50 nm, black arrows) were seen inside the cytoplasm; bar, $0.2 \mu \mathrm{m}$

\section{Specific humoral immunity in mice primed with pVAXzenv and boosted with FPzenv}

To develop a preventive vaccination strategy against ZIKV infection, an immunization protocol was set up to verify the capability of pVAXzenv and FPzenv recombinants to elicit antibodies against the Env protein, following a prime-boost strategy. The specific humoral

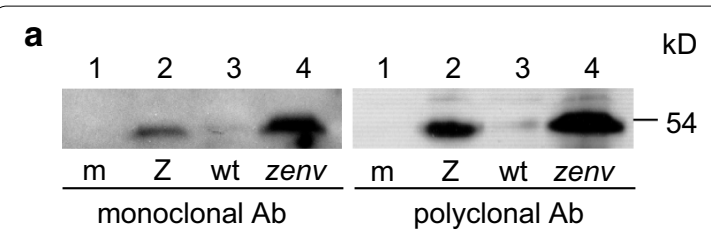

b

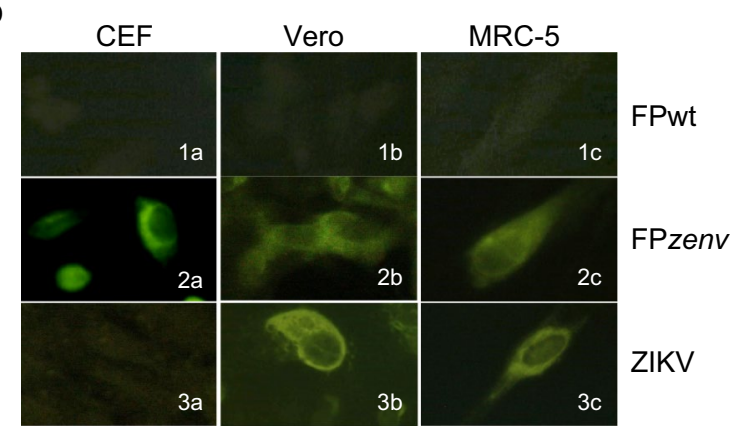

c

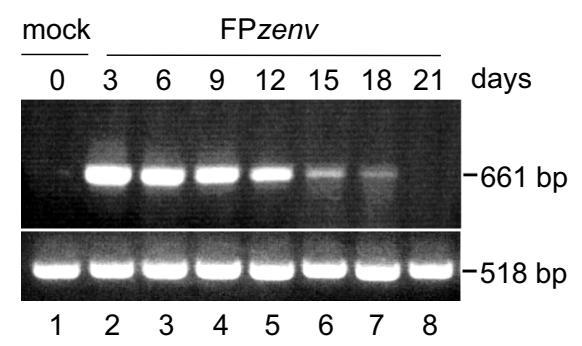

d

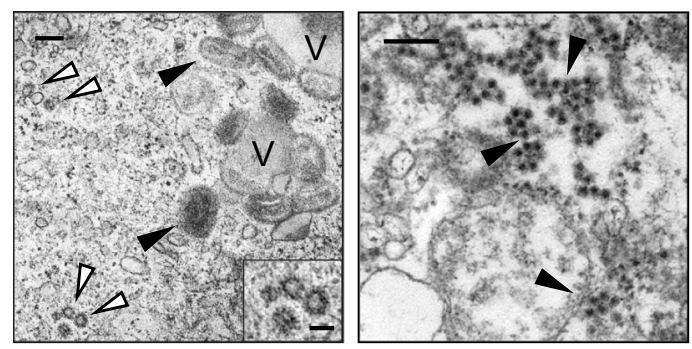

(See figure on next page.)

Fig. 3 a Immunization protocols. Two different vaccination regimens (control, G1; experimental, G2) were followed using 7 mice per group. Two DNA recombinants were used for priming (pVAXgp, pVAXzenv, respectively), and two viral recombinants expressing the same genes were used for the boost (FPgp, FPzenv, respectively). The DNAgp and FPgp recombinants that contained the HIV-1 gag/pro genes were used as irrelevant immunogens. Each plasmid was administered in vivo by electroporation $(10+50 \mu \mathrm{g} / \mathrm{recombinant} / \mathrm{mouse})$, and each virus was administered subcutaneously or intranasally $\left(1 \times 10^{6} \mathrm{PFU} /\right.$ recombinant/mouse). The challenge with ZIKV was administered subcutaneously at $1 \times 10^{5} \mathrm{PFU} /$ mouse. The mice were bled before each immunization, just before the ZIKV challenge (T6) and at further times after the challenge. $\mathbf{b}$ Analysis of the humoral immune response. The anti-Env antibody response was determined by ELISA, where Vero cells were infected with FPzenv and then lysed, as the plate-bound antigen. Serum was obtained from all of the mice at different times before each immunization, as well as before and after the ZIKV challenge. Each line represents an individual animal. Total IgG ELISA titres are shown. An anti-ZIKV Env-specific binding antibody response was seen soon after vaccination (G2, T4). It can be noted that at 10 weeks postvaccination, after boosting the animals by the intranasal route, the antibody titer was significantly higher as compared to the control mice ( $G 2$ vs $G 1, T 5 ; A U C, p<0.05)$. $O D_{450}$ is expressed after subtraction of the T0 values for each mouse. c Neutralizing activity using 1:50 serum dilution. Viral neutralization activity was determined using for each animal the pre-immune serum (T0) and sera from bleedings after the last immunization (T6). No inhibition of viral infectivity was found. Plaque numbers did not decrease when using hyper-immune or pre-immune sera (T6 vs T0) in the experimental vs the control animals (G2 vs G1) 
a
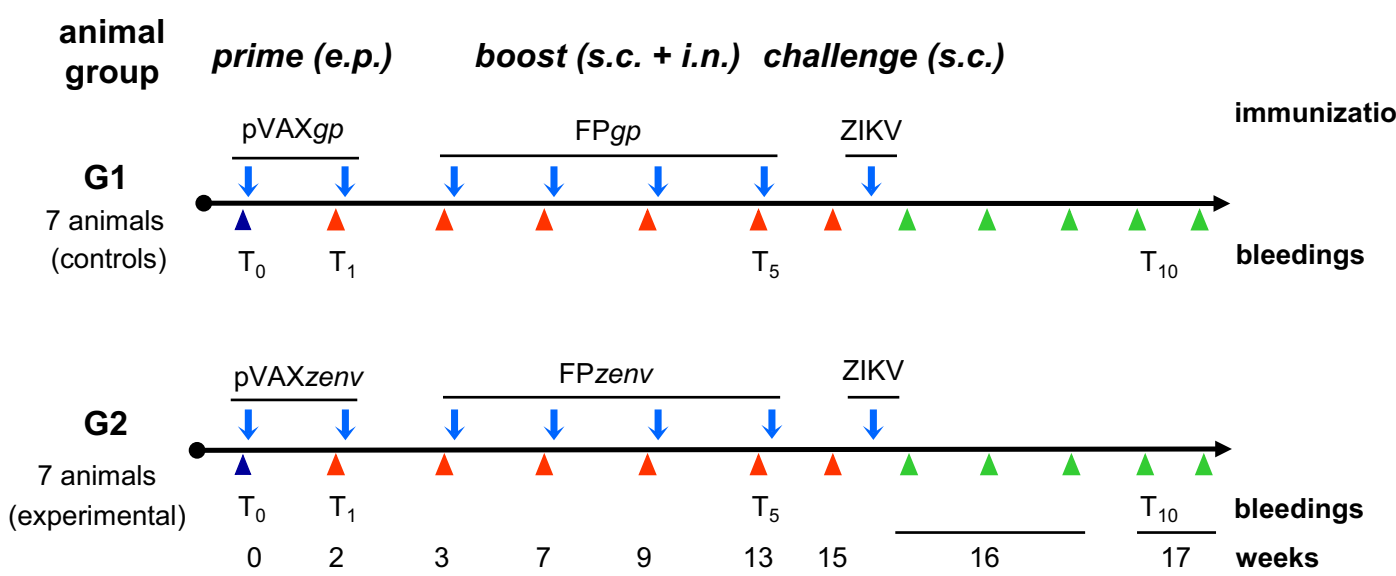

b

G1

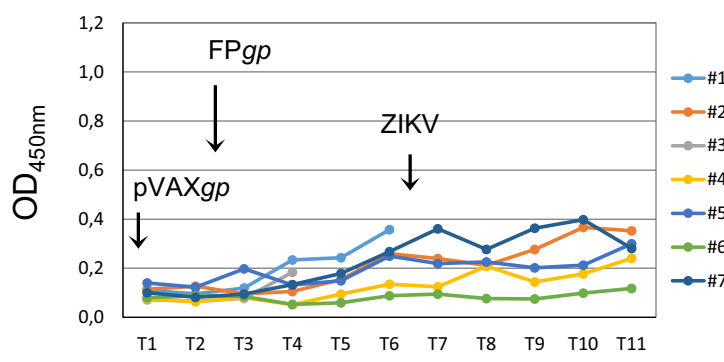

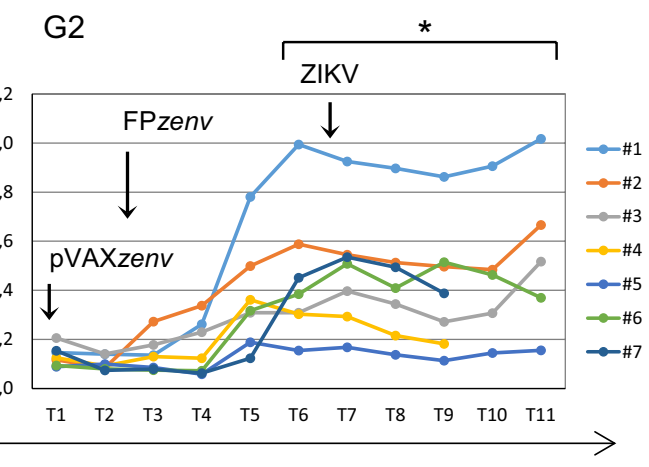

bleedings

G2 c $\quad$ G1

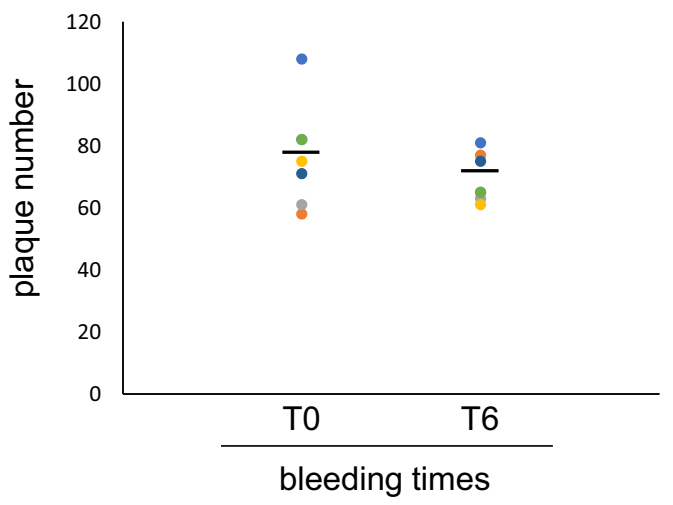

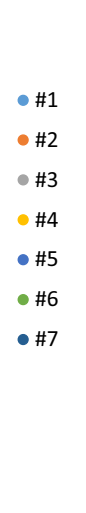

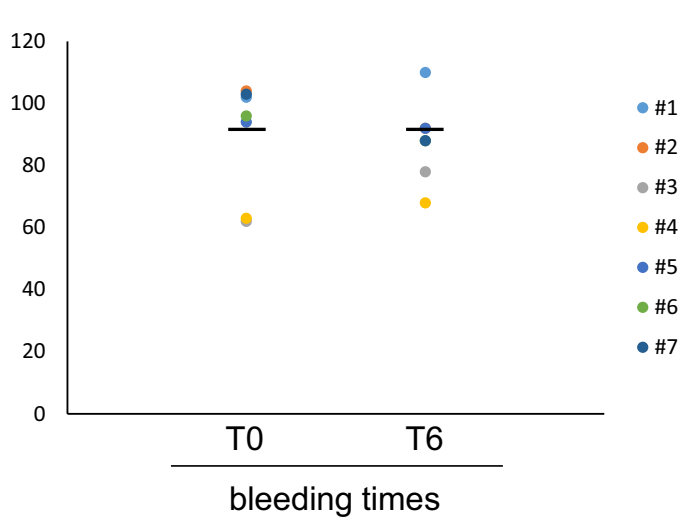

responses were measured using ELISA, for individual sera samples from the immunized mice and the lysates of the FPzenv-infected cells as the plate-bound antigens (Fig. 3b). The anti-ZIKV Env-specific binding antibody response in experimental mice, which received the pVAXzenv plus FPzenv (Fig. 3b, G2), was evident soon after vaccination. In particular, the antibody titer became significantly higher at 10 weeks post-vaccination, as compared to the control mice immunized with the irrelevant pVAXgp plus FPgp recombinants (Fig. 3b, G2 vs G1, T5; $\mathrm{p}<0.05)$. This increase corresponded to the T4 FPzenv boost, which was performed by the i.n. mucosal route. No 
significant specific immune responses were seen using the sera of the control mice (Fig. 3b, G1). No specific antibodies were seen with ELISA for plating of inactivated ZIKV or the recombinant domain-III ZIKV specific protein as a plate-bound antigen (data not shown).

\section{No neutralizing activity against ZIKV is seen}

To determine the putative pre-challenge immune correlates of the protection against ZIKV, viral neutralization assays were performed using the sera at T0 and T6, for both the negative control (G1) and the experimental group (G2) (Fig. 3c). Inhibition of viral infectivity, expressed as a decrease in the number of lysis plaques after incubating the serum with the virus, was not detected. For each animal, plaque numbers did not decrease when using hyper-immune $v s$ pre-immune sera (Fig. 3c, G2, T6 vs T0). Also, they did not essentially differ in the experimental (G2) and control (G1) animals. The number of plaques did not also change when different serum concentrations were used (data not shown).

\section{Challenge after dexamethasone-immunosuppression does not change the outcome of the mice}

To determine the protective efficacy of the vaccineinduced immune responses, the mice were challenged with ZIKV after dexamethasone immunosuppression. Post-challenge sera from all of the animals of both groups were used to extract RNA, but no ZIKV genome was detected by RT-PCR (data not shown).

\section{Discussion}

The link between ZIKV infections and severe congenital disease has prompted the development and evaluation of many candidate vaccines against ZIKV $[1,29]$. These studies have been facilitated by prior experience with multiple successful flavivirus vaccine approaches, and by immunity evaluated in preclinical and clinical studies [29].

In particular, the antiparallel Env protein dimers found on virions are considered as the most suitable antigens for vaccine design, as this structural protein is the main target of neutralizing antibodies. The amino-acid sequence of the Env protein is also $>99 \%$ conserved across the three ZIKV lineages [56]. VLPs also share morphological and antigenic properties with infectious virus particles [57]. Thus, most vaccines have been developed to encode the ZIKV PrME sequence [22, 24], also using constructs with consensus $\operatorname{PrME}$ sequences from multiple ZIKV strains (downstream of the signal sequence of IgE) [17]. These vaccines have shown good safety profiles, induction of neutralizing antibodies, and protection from viremia. Inactivated vaccines have also been shown to be protective against virus challenges and to elicit neutralizing antibodies $[16,22,25]$, although their development is no longer pursued. Live attenuated vaccines have also been investigated through the introduction of deletions or using chimeric flaviviruses $[26,58]$, and these have proved to be immunogenic and protective in mouse and nonhuman primate models [28]. In particular, the purified inactivated ZIKV by Larocca et al. [22] was modified by replacing the PrME signal sequence with the Kozak and the Japanese encephalitis virus leader sequence to optimize and enhance the env gene expression. The capsidterminal 18 amino acid signal sequence of $\operatorname{PrME}$ [41, 42] was also used for the construction of a vacciniavirus based recombinant [59]. This was obtained by the new Sementis Copenhagen Vector vaccine technology in CHO cells, and the deletion of the D13L gene, important for virus replication. Although homologous recombination was also used, clone selection by the fluorescent blue protein fused to the Zeocin resistance protein may be more cumbersome if compared to the clone selection with the $e n v$-specific radioactive probe that we always use.

Here we tested two novel recombinants expressing the $\operatorname{PrME}$ sequence in a prime-boost model under the capsid natural signal sequence, where pVAXzenv and FPzenv were used following the prime-boost strategy. To note, avipox-based recombinants do not cause the undesired side effects induced by vaccinia-based recombinants, and they are not neutralized in smallpox-vaccine experienced human subjects [33].

In spite of the progress that has been made, some issues still need to be resolved before licensing an effective prophylactic vaccine. In particular, pre-existing immunity to other flaviviruses can hamper the response to ZIKV immunization efficacy. It will also be important to verify a protective immune response against all the three ZIKV strains (i.e., West African, East African, Asian) [1].

With the aim being to improve immune responses against the env transgene, in the present study the mice were immunized following a heterologous prime-boost regimen. Furthermore, to determine whether a different administration route might improve the humoral responses, different routes were used for the FPzenv administration. In particular, dexamethasone-immunosuppressed BALB/c mice were used for the ZIKV challenge [54]. These data demonstrate that: (i) the ZIKV Env protein is correctly expressed by both human MRC- 5 and simian Vero cells infected with FPzenv; (ii) FPzenv expresses the transgene in Vero cells for more than 2 weeks; and (iii) after mucosal administration of the avipox recombinant, the humoral response is significantly higher in the experimental mice, compared to the control mice. 
The Western blotting shows that polyclonal and monoclonal antibodies can recognize the ZIKV Env protein expressed by FPzenv. The correct and long-lasting production of the transcript by Vero cells infected with FPzenv persisted for $\geq 18$ days p.i., which, in spite of the mRNA decrease that started from day 12 p.i., might translate into long-lasting stimulation of the immune response. The intensity of the $\beta$-actin band was similar in the different samples, which supported the correct interpretation of the expression trend.

FPzenv was also tested for its production of VLPs using electron microscopy, and they were detected in low amounts in Vero cells. This suggests potential further stimulation of the immune system by these particles that mimic the original conformation of the virus.

A specific humoral response was obtained in the mice immunized with the experimental vaccine, with a significant increase when the FPzenv boost was performed by mucosal immunization. This suggests that in spite of the use of the conventional subcutaneous immunization route and the physiological injection of the virus by insect bite, a significant increase in the antibody response was obtained only when the mice were boosted intranasally. Most neutralizing antibodies target determinants in domain III or the fusogenic loop of domain II of the Env protein, and also protect after passive transfer in lethal mouse models of infection [60], which confirms the important role of humoral immunity. In our case, specific antibodies were not detected when using nonpurified ZIKV or domain III of the ZIKV Env protein. It is still not clear why the antibodies did not recognize nonpurified ZIKV, but we can hypothesize partial inaccessibility of the conformational epitopes on the mature virions. This might also explain the lack of binding to the DIII region of the $\mathrm{E}$ protein dimer that can recognize and neutralize ZIKV [61]. However, these antibodies did not neutralize ZIKV, as the number of viral plaques was almost the same when using the control and experimental sera, and was very similar to the number generated when the virus was incubated with preimmune serum (T0). It is known that, although many epitopes of ZIKV are very similar to those of other flaviviruses, higher concentrations of antibodies are needed for virus neutralization compared to other flaviviruses [29]. We have also previously demonstrated that the specific neutralizing response may be hidden by the aspecific activity, detected in naïve mice or in control mice immunized with irrelevant immunogens [44]. However, our previous study showed that vaccinated mice can be protected and survive also when a very low neutralization titer is used, with an increase in specific $v s$ aspecific antibodies.

For the mice, weight losses after challenge progressed, although with no mortality among the animals, with some differences between the challenged control and experimental mice that did not reach significance. As all of the animals survived, it was also important to verify whether the virus was present in the serum soon after the challenge and in the 10 days thereafter. As the virus was never found, we can hypothesize inadequate immune suppression by dexamethasone, which might have translated into premature neutralization/inactivation of the virus, before its diffusion. This might be in agreement with the presence of mouse factors in the preimmune serum that can neutralize the virus.

Overall, although the mice were challenged s.c. to mimic the physiological virus inoculation, the data show that only the boost by the mucosal route enhanced the humoral responses. This might also suggest a future different use of the administration route with a possible reduction of the boosts to induce neutralizing antibodies.

Although virus neutralizing antibodies are generally considered as a surrogate of protective immunity for some licensed flavivirus vaccines [62], and different candidate vaccines exhibit neutralizing activity [28], results from different studies are using different not-comparable neutralization assays and repeated vaccine doses are required to have a titer able to protect the animals [29].

\section{Conclusion}

Viral vectors represent a promising immunization strategy against emerging viruses, as they have already been shown to elicit both humoral and cell-mediated immunity. Their low production costs also contribute to favor their development. Different research groups have already used different strategies with vaccinia and adenovirus-based live vector candidates, to increase their efficacy in the absence of pathogenicity $[16,18,22,25$, $28,59]$. Even if such recombinant vaccines can be highly immunogenic, questions remain as to their safety in some target populations [63]. Attenuated strains of vaccinia virus have also been tried, but antibodies against the vector were also found in the mouse model [64], which are not found by immunization with avipox-vector recombinants.

Susceptible mice models that maintain the natural competent immune responses should be the first choice to test vaccine efficacies, as impaired immune responses can hamper vaccine protection [65]. In our study, although BALB/c mice appear to be an adequate model for ZIKV infection, as it mimics the natural mild infection in human beings, with a short viremic phase [66], immune suppression by dexamethasone did not result in the expected viral replication in control mice. Therefore, different immune suppression strategies should be applied to reveal any protection before challenge as well as other animal models. Interferon-receptor-deficient 
immunocompromised mice can represent another strategy, by using AG129 Ifnor1-/- mice, which lack receptors for both type I $(\alpha / \beta)$ and type II $(\gamma)$ interferons [67], or mice treated with antibodies against interferon.

\section{Abbreviations}

CEFs: Chicken embryo fibroblasts; DMEM: Dulbecco's modified Eagle's medium; FP: Fowlpox; VLPs: Virus like particles; ZIKV: Zika virus.

\section{Acknowledgements}

The authors also thank Dr. Christopher P. Berrie for editorial assistance with the manuscript.

\section{Authors' contributions}

CZ performed the experiments and prepared the Figures; FP performed the vaccination by electroporation; CDGM and AR designed, conceptualized, and supervised the whole study, analyzed the data, and prepared the manuscript. All of the authors have read and approved the present version of the manuscript.

\section{Funding}

This study was partially funded by a University of Milan Transition Grant, code no. 18498, CUP G42114001030001. This study was also supported in part by NATO funding INTLI19CZANO_01. All of the authors have read and approved the present version of the manuscript. This publication was also supported by the European Virus Archive goes Global (EVAg) project, which has received funding from the European Union ${ }^{\mathrm{TM}}$ Horizon 2020 Research and Innovation Programme, under grant agreement No 653316.

\section{Availability of data and materials}

The authors make the data supporting their findings available upon request to the corresponding or to the first author.

\section{Ethics approval and consent to participate}

The animals were maintained according to the Italian National Guidelines and the EU Directive 2010/63/EU for animal experiments. Approval for this study was granted by the Ethical Committee of the University of Milan.

\section{Consent to publication}

Not applicable.

\section{Competing interests}

The authors declare that they have no competing interests, and that the manuscript has been approved by all of the authors for publication in its present form.

\begin{abstract}
Author details
'Laboratory of Molecular Virology and Recombinant Vaccine Development, Department of Medical Biotechnologies and Translational Medicine, University of Milan, Via Vanvitelli 32, 20129 Milan, Italy. ${ }^{2}$ HPV-UNIT, Laboratory of Virology, Regina Elena National Cancer Institute, Via delle Messi d'Oro, 156, 00158 Rome, Italy. ${ }^{3}$ Catholic University "Our Lady of Good Counsel", Rr. Dritan Hoxha, 123, Tirana, Albania.
\end{abstract}

Received: 13 July 2020 Accepted: 19 February 2021

Published online: 04 March 2021

\section{References}

1. Poland GA, Kennedy RB, Ovsyannikova I, Palacios R, Ho PL, Kalil J. Development of vaccines against Zika virus. Lancet Infect Dis. 2018;18:212-9.

2. Wikan N, Smith DR. Zika virus: history of a newly emerging arbovirus. Lancet Infect Dis. 2016;16:E119-26.

3. Dejnirattisai W, Supasa P, Wongwiwat W, Rouvinski A, Barba-spaeth G, Duangchinda T, Sakuntabhai A, Malasit P, Rey FA. Dengue virus sero-crossreactivity drives antibody- dependent enhancement of infection with zika virus. Nat Immunol. 2016;17:1102-8.
4. Mlakar J, Korva M, Tul N, Popovic M, Poljšak-Prijatelj M, Mraz J, Kolenc M, Rus KR, Vipotnik TV, Vodušek VF, Vizjak A, Pižem J, Petrovec M, Županc TA. Zika Virus Associated with Microcephaly. N Engl J Med. 2016;374:951-8.

5. Russell K, Hills SL, Oster AM, Porse CC, Danyluk G, Cone M, Brooks R, Scotland S, Schiffman E, Fredette C. Male-to-female sexual transmission of Zika Virus — United States, January-April 2016. Clin Infect Dis. 2017;64:211-3.

6. Grard G, Caron M, Mombo IM, Nkoghe D, Mboui Ondo S, Jiolle D, Fontenille D, Paupy C, Leroy EM. Zika Virus in Gabon (Central Africa). PLoS Negl Trop Dis. 2014;8:1-6.

7. MacNamara FN. Zika virus: a report on three cases of human infection during an epidemic of jaundice in Nigeria. Trans R Soc Trop Med Hyg. 1954;48:139-45.

8. Duffy MR, Chen TH, Hancock WT, Powers AM, Kool JL, Lanciotti RS, Pretrick M, Marfel M, Holzbauer S, Dubray C, Guillaumot L, Griggs A, Bel M, Lambert AJ, Laven J, Kosoy O, Panella A, Biggerstaff BJ, Fischer M, Hayes EB. Zika virus outbreak on Yap Island, Federated States of Micronesia. N Engl J Med. 2009;360:2536-43.

9. Musso D, Nilles EJ, Cao-Lormeau VM. Rapid spread of emerging Zika virus in the Pacific area. Clin Microbiol infect. 2014;20:595-6.

10. Musso D, Gubler DJ. Zika virus. Clin Microbiol Rev. 2016;29:487-524.

11. Krauer F, Riesen M, Reveiz L, Oladapo OT, Martinez-Vega R, Porgo TV, Haefliger A, Broutet NJ, Low N, WHO Zika Causality Working Group. Zika virus infection as a cause of congenital brain abnormalities and guillain-barré syndrome: systematic review. PLoS Med. 2017;14:1-27.

12. Tang H, Hammack C, Ogden SC, Wen Z, Qian X, Li Y, Lee EM, Christian KM, Didier RA, Jin P. Zika virus infects human cortical neural progenitors and attenuates their growth. Cell Stem Cell. 2016;18:587-90.

13. Fauci AS, Morens DM. Zika virus in the Americas - yet another arbovirus threat. N Engl J Med. 2016;374:601-4.

14. Vogel G. One year later, Zika scientists prepare for a long war. Science. 2016;354:1888-97.

15. Fernandez E, Diamond MS. Vaccination strategies against Zika virus. Curr Opin Virol. 2017;23:59-67.

16. Abbink P, Larocca RA, Visitsunthorn K, Boyd M, De La Barrera RA, Gromowski G, Kirilova M, Peterson R, Li Z, Nanayakkara O, Nityanandam R, Mercado NB, Borducchi EN, Chandrashekar A, Jetton D, Mojta S, Gandhi P, LeSuer J, Khatiwada S, Lewis MG, Modjarrad K, Jarman RG, Eckels KH, Thomas SJ, Michael NL, Barouch DH. Durability and correlates of vaccine protection against Zika virus in rhesus monkeys. Sci Transl Med. 2017;9:pii: eaao4163.

17. Griffin BD, Muthumani K, Warner BM, Majer A, Hagan M, Audet J, Stein DR, Ranadheera C, Racine T, De La Vega MA, Piret J, Kucas S, Tran KN, Frost KL, De Graff C, Soule G, Scharikow L, Scott J, McTavish G, Smid V, Park JK, Maslow JN, Sardesai NY, Kim JJ, Yao XJ, Bello A, Lindsay R, Boivin G, Booth SA, Kobasa D, Embury-Hyatt C, Safronetz D, Weiner DB, Kobinger GP. DNA vaccination protects mice against Zika virus-induced damage to the testes. Nat Commun. 2017;8:15743.

18. Guo Q, Chan JF, Poon VK, Wu S, Chan CC, Hou L, Yip CC, Ren C, Cai JP, Zhao M, Zhang AJ, Song X, Chan KH, Wang B, Kok KH, Wen Y, Yuen KY, Chen W. Immunization with a novel human type 5 adenovirus-vectored vaccine expressing the premembrane and envelope proteins of zika virus provides consistent and sterilizing protection in multiple immunocompetent and immunocompromised animal models. J Infect Dis. 2018;218:365-77.

19. Prow NA, Liu L, Nakayama E. A vaccina-based single vector construct multi-pathogen vaccine protects both Zika and chikungunya viruses. Nat Commun. 2018;9:1230.

20. Boigard H, Alimova A, Martin GR, Katz A, Gottlieb P, Galarza JM. Zika viruslike particle (VLP) based vaccine. PLoS Negl Trop Dis. 2017;11:e0005608.

21. Garg H, Sedano M, Plata G, Punke EB, Joshi A. Development of virus-like-particle vaccine and reporter assay for Zika virus. J Virol. 2017;91:e00834-e917.

22. Richner JM, Himansu S, Dowd KA, Butler SL, Fox JM. Modified mRNA vaccines protect against zika virus infection. Cell. 2017;169:176.

23. Pardi N, Hogan MJ, Pelc RS, ndersen H, DeMaso CR. Zika virus protection by a single low-dose nucleoside-modified mRNA vaccination. Nature. 2017:543:248-299.

24. Dowd KA, Ko SY, Morabito KM, Yang ES, Pelc RS, DeMaso CR. Rapid development of a DNA vaccine for Zika virus. Science. 2016;354:237-77. 
25. Abbink P, Larocca RA, Bricault CA, Moseley ET, Boyd M. Protective efficacy of multiple vaccine platforms against Zika virus challenge in rhesus monkeys. Science. 2016:353:1129-32.

26. Shan C, Muruato AE, Nunes BTD, Luo H, Xie X, Medeiros DBA, Wakamiya M, Tesh RB, Barrett AD, Wang T, Weaver SC, Vasconcelos PF, Rossi SL, Shi PY. A live-attenuated Zika virus vaccine candidate induces sterilizing immunity in mouse models. Nat Med. 2017;23:763-7.

27. Yang M, Dent M, Sun H, Chen Q. Immunization of Zika virus envelope protein domain III induces specific and neutralizing immune responses against Zika virus. Vaccine. 2017;35:4287-94.

28. Diamond MS, Legerwood JE, Pierson TC. Zika virus vaccine development: progress in the face of new challenges. Annu Rev Med. 2018;70:121-35.

29. Barrett ADT. Current status of Zika vaccine development: Zika vaccines advance into clinical evaluation. Vaccines. 2018;3:24.

30. Dittmer U, Brooks DM, Hasenkrug KJ. Requirement for multiple lymphocyte subsets in protection by a live attenuated vaccine against retroviral infection. Nat Med. 1999;5:1891-3.

31. Heeney $J$, Holterman L, ten Haaft P, Dubbes R, Koomstra W, Teeuwsen VJP, Bourquin P, Norley S, Niphuis H. Vaccine protection and reduced virus load from heterologous macaque-propagated SIV challenge. AIDS Res Hum Retroviruses. 1994;10:S117-121.

32. De Giuli MC, Radaelli A, Zanotto C, Marconi P, Manservigi R. Virus vectors for immunoprophylaxis. AIDS Rev. 2000;2:127-35.

33. Baxby D, Paoletti E. Potential use of nonreplicating vectors as recombinant vaccines. Vaccine. 1992;10:8-9.

34. Nacsa J, Radaelli A, Edghill-Smith Y, Venzon D, Tsai WP, De Giuli MC, Panicali DL, Tartaglia J, Franchini G. Avipox-based simian immunodeficiency virus (SIV) vaccines elicit a high frequency of SIV-specific CD4+ and CD8+ T-cell responses in vaccinia-experienced SIVmac251-infected macaques. Vaccine. 2004;22:597-606.

35. Clements-Mann ML, Weinhold K, Matthews TJ, Graham BS, Gorse GJ, Keefer MC, McElrath MJ, Hsieh R-H, Mestecky J, Zolla-Pazner S, Mascola J, Schwartz D, Siliciano R, Corey L, Wright PF, Belshe R, Dolin R, Jackson S, Xu S, Fast P, Walker MC, Stablein D, Excler JL, Tartaglia J, Duliege A-M, Sinangil F, Paoletti E. Immune responses to human immunodeficiency virus (HIV) type 1 induced by canarypox expressing HIV-1(MN) gp120, HIV-1(SF2) recombinant gp120, or both vaccines in seronegative adults. J Infect Dis. 1998:177:1230-46.

36. Skinner MA, Laidlaw SM, Eldaghayes I, Kaiser P, Cottingham MG. Fowlpox virus as a recombinant vaccine vector for use in mammals and poultry. Expert Rev Vaccines. 2005;4:63-76.

37. Taylor J, Weinberg R, Languet B, Desmettre P, Paoletti E. Recombinant fowlpox virus inducing protective immunity in nonavian species. Vaccine. 1988;6:497-503.

38. Zanotto C, Pozzi E, Pacchioni S, Volonté L, De Giuli MC, Radaelli A. Canarypox and fowlpox viruses as recombinant vaccine vectors: a biological and immunological comparison. Antiviral Res. 2010;88:53-63.

39. Dai L, Song J, Lu X, Deng YQ, Musyoki AM. Structures of the zika virus envelope protein and its complex with a flavivirus broadly protective antibody. Cell Host Microbe. 2016;19:696-704.

40. Pardy RD, Rajah MM, Condotta SA, Taylor NG, Sagan SM. Analysis of the T cell response to zika virus and identification of a novel CD8+ T cell epitope in immunocompetent mice. PLoS Negl Trop Dis. 2017;13:e1006184.

41. Kuno G, Chang G-J. Full-length sequencing and genomic characterization of Bagaza, Kedougou, and Zika viruses. Arch Virol. 2007;152:687-96.

42. Prasad VM, Miller AS, Klose T, Sirohi D, Buda G, Jiang W, Kuhn RJ, Rossmann MG. Structure of the immature Zika virus at $9 \AA$ resolution. Nat Struct Mol Biol. 2017;24:184-6.

43. Bissa M, Pacchioni S, Zanotto C, De Giuli MC, Illiano E, Granucci F, Zanoni I, Broggi A, Radaelli A. Systemically administered DNA and fowlpox recombinants expressing four vaccinia virus genes although immunogenic do notprotect mice against the highly pathogenic IHD-J vaccinia strain. Virus Res. 2013;178:374-82.

44. Bissa M, Quaglino E, Zanotto C, Illiano E, Rolih V, Pacchioni S, Cavallo F, De Giuli MC, Radaelli A. Protection of mice against the highly pathogenic VVIHD-J by DNA and fowlpox recombinant vaccines, administered by electroporation and intranasal routes, correlates with serum neutralizing activity. Antiviral Res. 2016;134:182-91.
45. Aiyar A, Leis J. Modification of the megaprimer method of PCR mutagenesis: improved amplification of the final product. Biotechniques. 1993:14:366-9.

46. Radaelli A, Zanotto C, Perletti G, Elli V, Vicenzi E, Poli G, De Giuli MC. Comparative analysis of immune responses and cytokine profiles elicited in rabbits by the combined use of recombinant fowlpox viruses, plasmid and virus-like particles in prime-boost vaccination protocols against SHIV. Vaccine. 2003;21:2052-64.

47. Rosel JL, Earl PL, Weir J, Moss B. Conserved TAAATG sequence at the transcriptional and translational initiation sites of vaccinia virus late genes deduced by structural and functional analysis of the hindlll $\mathrm{H}$ genome fragment. J Virol. 1986;60:436-49.

48. Bissa M, Pacchioni S, Zanotto C, De Giuli MC, Radaelli A. GFP co-expression reduces the A33R gene expression driven by a fowlpox vector in replication permissive and non-permissive cell lines. J Virol Methods. 2013;187:172-6.

49. Pacchioni S, Volonté L, Zanotto C, Pozzi E, De Giuli MC, Radaelli A. Canarypox and fowlpox viruses as recombinant vaccine vectors: an ultrastructural comparative analysis. Arch Virol. 2010;155:915-24.

50. Bissa M, Forlani G, Zanotto C, Tosi G, De Giuli MC, Accolla R, Radaelli A. Fowlpoxvirus recombinants coding for the CIITA gene increase the expression of endogenous MHC-II and Fowlpox Gag/Pro and Env SIV transgenes. PLoS ONE. 2018;13:1-23.

51. Radaelli A, De Giuli MC, Zanotto C, Pacchioni S, Bissa M, Franconi R, Massa S, Paolini F, Muller A, Venuti A. A prime/boost strategy by DNA/fowlpox recombinants expressing a mutant E7 protein for the immunotherapy of HPV-associated cancers. Virus Res. 2012;170:44-52.

52. Bissa M, Illiano E, Pacchioni S, Paolini F, Zanotto C, De Giuli MC, Massa S, Franconi R, Radaelli A, Venuti A. A prime/boost strategy using DNA/ fowlpox recombinants expressing the genetically attenuated E6 protein as a putative vaccine against HPV-16-associated cancers. J Transl Med. 2015;13:80-91

53. Pozzi E, Basavecchia V, Zanotto C, Pacchioni S, De Giuli MC, Radaelli A. Construction and characterization of recombinant fowlpox viruses expressing human papilloma virus E6 and E7 oncoproteins. J Virol Methods. 2009;158:184-9.

54. Chan JF, Zhang AJ, Chan CC, Yip CC, Mak WW, Zhu H, Poon VK, Tee KM, Zhu Z, Cai JP, Tsang JO, Chik KK, Yin F, Chan KH, Kok KH, Jin DY, Au-Yeung RK, Yuen KY. Zika virus infection in dexamethasone-immunosuppressed mice demonstrating disseminated infection with multi-organ involvement including orchitis effectively treated by recombinant type I interferons. EBioMedicine. 2016;14:112-22.

55. Radaelli A, Pozzi E, Pacchioni S, Zanotto C, De Giuli MC. Fowlpox virus recombinants expressing HPV-16 E6 and E7 oncogenes for the therapy of cervical carcinoma elicit humoral and cell-mediated responses in rabbits. J Transl Med. 2010;8:40.

56. Lanciotti RS, Lambert AJ, Holodniy M, Saavedra S, del Carmen Castillo Signor L. Phylogeny of Zika virus in western hemisphere, 2015. Emerging infectious diseases. 2016;22:933-935.

57. Zanotto C, Paganini M, Elli V, Basavecchia V, Neri M, De Giuli MC, Radaelli A. Molecular and biological characterization of simian-human immunodeficiency virus-like particles produced by recombinant fowlpox viruses. Vaccine. 2005;23:4745-53.

58. Xie X, Yang Y, uruato AE. Understanding Zika virus stability and developing a chimeric vaccine through functional analysis. MBio. 2017;8:e02134-16.

59. Prow NA, Liu L, Nakayama E. A vaccina-based single vector construct multi-pathogen vaccine protects against both Zika and chikungunya viruses. Nat Commun. 2018:9:1-11.

60. Zhao H, Fernandez E, Dowd KA. Structural basis of Zika virus-specific antibody protection. Cell. 2016;166:1016-27.

61. Barba-spaeth G, Dejnirattisai W, Rouvinski A. Structural basis of potent Zika-dengue virus antibody cross-neutralizzation. Nature. 2016;536:48-53.

62. Barrett AD. Zika vaccine candidates progress through nonclinical development and enter clinical trials. NPJ Vaccines. 2016;1:16023.

63. Durbin AP, Kirkpatrick BD, Pierce KK, Grier PL, Hynes N, Opert K, Jarvis AP, Sabundayo BP. A 12-Month-Interval Dosing Study in Adults Indicates That a Single Dose of the National Institute of Allergy and Infectious Diseases Tetravalent Dengue Vaccine Induces a Robust Neutralizing Antibody Response. J Infect Dis. 2016;214:832-5. 
64. Zhan Y, Den Y, Tan W. Humoral and cellular immunity against both ZIKV and poxvirus is elicited by a two-dose regimen using DNA and non-replicating vaccina virus-based vaccine candidates. Vaccine. 2019;37:2122-30.

65. Gorman MJ, Caine EA, Zaitsev K. An Immunocompetent Mouse Model of Zika Virus Infection. Cell Host Microbe. 2018;23:672-85.

66. Larocca RA, Peron JP, Abbink P. Vaccine protection against Zika virus from Brazil. Nature. 2016;536:474-8
67. Touret F, Gilles M, Klitting R, Aubry F, deLamballerie X, Nougairede A. Live Zika Virus chimeric vaccine candidate based on a yellow fever 17-D attenuated backbone. Emerg Microbes Infect. 2018;7:161.

\section{Publisher's Note}

Springer Nature remains neutral with regard to jurisdictional claims in published maps and institutional affiliations.
Ready to submit your research? Choose BMC and benefit from:

- fast, convenient online submission

- thorough peer review by experienced researchers in your field

- rapid publication on acceptance

- support for research data, including large and complex data types

- gold Open Access which fosters wider collaboration and increased citations

- maximum visibility for your research: over $100 \mathrm{M}$ website views per year

At BMC, research is always in progress.

Learn more biomedcentral.com/submissions 